\title{
Efektivitas Penggunaan Kombinasi Vitamin B pada Pasien Neuropati Diabetikum
}

Rizaldy Taslim Pinzon*, Rosa De Lima Renita Sanyasi

Fakultas Kedokteran, Universitas Kristen Duta Wacana, Yogyakarta

*Corresponding author: drpinzon17@gmail.com

\begin{abstract}
Background: Diabetic neuropathy $(D N)$ is the most common type of neuropathy. The current medications are only for symptom control. Vitamin B combination administration not only for symptom control, but also improve the nerve function. Previous studies about the benefit of vitamin B combination for diabetic neuropathy are limited and inconclusive. Objective: This study measured the effectivity of vitamin B combination to reduce diabetic neuropathy symptoms and improving quality of life $(Q o L)$. Methods: This study was an observational study on diabetic mellitus patients with diabetic neuropati. Each subject was given vitamin $B$ combination consists of vitamin $B_{1}$, vitamin $B_{6}$, dan vitamin $B_{12}$, with dosage $100 \mathrm{mg}, 100 \mathrm{mg}$, and $5 \mathrm{mg}$ respectively. DN symptoms were measured by using Total Symptom Score (TSS). QoL was measured by using SF-8 questionnaire. Follow-up was performed 5 times, with the total length of study was 3 months. Results: There were 104 subjects. Seven subjects were not complete the study. Complete follow up are 97 (93.3\%) subjects. Improvement in four $D N$ symptoms (stabbing pain, burning pain, parasthesia, and numbness) showed in this study, compared from the baseline to fifth follow-up. The improvement was significant $(p<0.0001)$. Quality of life score was increasing after 3 months medication using vitamin B combination. The differences between baseline score to fifth follow-up score were statistically significant (physical component summary: $p<0.0001$ and mental component summary: $p=0.0001)$. Conclusion: Combination of vitamin $B$ is effective to improve symptoms and QoL in DN patients.
\end{abstract}

Keywords: vitamin B combination, diabetes mellitus, diabetic neuropathy, TSS, SF-8

\begin{abstract}
Abstrak
Pendahuluan: Neuropati diabetikum (ND) adalah salah satu bentuk neuropati yang paling umum dijumpai. Terapi yang ada saat ini lebih ditujukan untuk mengatasi gejala. Pemberian kombinasi vitamin B ditujukan bukan hanya untuk mengendalikan gejala, namun memperbaiki fungsi saraf. Penelitian terdahulu tentang vitamin untuk neuropati diabetika masih terbatas dan belum konklusif. Tujuan: Penelitian ini bertujuan untuk menilai efektivitas vitamin B kombinasi terhadap gejala klinis neuropati diabetika dan kualitas hidup (QoL) pada pasien diabetes melitus (DM). Metode: Metode yang digunakan dalam penelitian ini adalah metode penelitian observasional pada pasien DM dengan ND. Setiap subjek memperoleh vitamin B kombinasi yang terdiri dari vitamin $B_{1}$, vitamin $B_{6}$, dan vitamin $B_{12}$ dengan dosis masing-masing secara berurutan $100 \mathrm{mg}, 100 \mathrm{mg}$, dan 5 mg. Gejala klinis ND dinilai dengan menggunakan Total Symptom Score (TSS). QoL dinilai dengan menggunakan kuesioner SF-8. Penilaian dilakukan sebanyak 5 kali, yaitu penilaian awal hingga 3 bulan. Hasil: Total terdapat 104 subjek pada awal penelitian. Tujuh subjek tidak dapat mengikuti penelitian sampai selesai, sehingga tersisa 97 subjek pada akhir penelitian. Terdapat perbaikan berbagai gejala ND, yang meliputi sensasi nyeri tertusuk, sensasi nyeri terbakar, kesemutan, dan rasa kebas/baal, setelah pemberian vitamin B kombinasi. Perubahan tersebut bermakna secara statistik $(\mathrm{p}<0,0001$ ). Hal serupa juga tampak pada QoL. Terdapat perbaikan QoL dari awal penelitian hingga akhir penelitian. Perbedaan tersebut bermakna secara statistik (physical component summary dengan $\mathrm{p}<0,0001$ dan mental component summary dengan $\mathrm{p}=0,0001$ ). Kesimpulan: Vitamin B kombinasi efektif untuk memperbaiki gejala klinis dan meningkatkan kualitas hidup pada pasien ND.
\end{abstract}

Kata kunci: vitamin B kombinasi, diabetes mellitus, neuropati diabetikum, TSS, SF-8 


\section{PENDAHULUAN}

Diabetes mellitus (DM) termasuk penyakit tidak menular yang sering dijumpai. Berdasarkan Riset Kesehatan Dasar 2013, jumlah penderita DM di Indonesia meningkat dari $1,1 \%$ pada tahun 2007 menjadi 2,4\% pada tahun 2013 (Badan Penelitian dan Pengembangan Kesehatan Kementerian Kesehatan Republik Indonesia, 2013).

ND merupakan komplikasi jangka panjang yang paling sering terjadi pada pasien DM. (Pop-Busui dkk., 2017; Papanas dkk., 2011). Sekitar 50\% penderita DM tipe 2 akan mengalami neuropati perifer (Kovac dkk., 2011; Tesfaye dkk., 2013). Terdapat 2 jenis gejala ND yang dapat dijumpai. Gejala positif ND meliputi sensasi nyeri tertusuk, sensasi nyeri terbakar, alodinia, dan sensasi diremas, sedangkan gejala negatif ND meliputi kesemutan dan rasa kebas/baal (Burns \& Mauermann, 2011).

Patofisiologi dari ND melibatkan banyak faktor, meliputi kerusakan mikrovaskular, neurodegenerasi, keterlibatan jalur polyol, stres oksidatif, dan proses inflamasi (Yagihashi dkk., 2010; Zychowska dkk., 2013). Faktor utama pemicu ND adalah hiperglikemia, sedangkan faktor lain yang berkontribusi meliputi usia tua, jenis kelamin laki-laki, durasi penyakit, hipertensi, merokok, konsumsi alkohol, dan kadar HbA1c > 7\%, (Deshpande dkk., 2008; Do Nascimento \& Cavalcanti, 2016).

Pasien DM dengan komplikasi ND sering terkait dengan kualitas hidup/quality of life (QoL) yang buruk (Deli dkk., 2013; Hosseini \& Abdollahi, 2013). Hal tersebut dapat berdampak baik pada fisik maupun psikologis pasien (Boyd dkk., 2011). Penanganan DM yang efektif, pencegahan sekaligus deteksi dini adanya ND akan mencegah perburukan QoL pada pasien. Terdapat berbagai terapi untuk menangani ND. Salah satu dari terapi tersebut adalah penggunaan kombinasi vitamin B. Penelitian di Indonesia mengenai penggunaan vitamin $B$ kombinasi pada pasien ND masih terbatas. Tujuan dari penelitian ini adalah menilai efektivitas pemberian vitamin B kombinasi terhadap gejala klinis dan QoL pada pasien ND.

\section{METODE}

\section{Subjek penelitian}

Penelitian ini merupakan penelitian observasional. Subjek dalam penelitian ini adalah pasien dengan ND. Kriteria inklusi meliputi: (i) usia $\geq 18$ tahun dan $\leq 65$ tahun, (ii) laki-laki maupun perempuan. Subjek yang memenuhi kriteria dan setuju untuk terlibat dalam penelitian diwajibkan untuk menandatangani lembar persetujuan penelitian yang telah disediakan. Diagnosis ND ditegakkan dengan menggunakan Michigan Neuropathy Screening Instrument (MNSI) atau Toronto Clinical Neuropathy Score (TCNS). MNSI terdiri dari dua bagian, yaitu (i) kuesioner, diisi oleh pasien yang terdiri dari 15 pertanyaan dan (ii) pemeriksaan yang dilakukan oleh tenaga medis, terdiri dari inspeksi (pemeriksaan deformitas, kulit kering, kalus, infeksi, fisura, dan ulkus), reflek tendo Achilles, dan sensasi vibrasi (Al-Geffari, 2012; Muntean dkk., 2016). TCNS diperiksa dengan memeriksa gejala neuropati (nyeri kaki, rasa kebas/baal, kesemutan, kelemahan, ataksia), sensoris (pemeriksaan pinprick, suhu, sentuhan ringan, vibrasi, dan propriosepsi), dan pemeriksaan refleks (refleks Achilles dan refleks patela) (Bril dkk., 2009). Pasien dikatakan mengalami neuropati apabila memiliki skor pada pengisian kuesioner MNSI oleh pasien adalah $\geq 7$ dan skor oleh tenaga medis $\geq 2,5$ atau skor TCNS $\geq 6$.

Kriteria eksklusi meliputi: (i) memiliki riwayat alergi terhadap vitamin B kompleks, (ii) memiliki riwayat neuropati perifer yang bersifat genetis atau familial, (iii) mengonsumsi suplemen vitamin B kompleks 1 bulan sebelumnya, (iv) terlibat dalam penelitian uji klinis lain 1 bulan sebelumnya, (v) sedang hamil, merencanakan kehamilan, atau menyusui, (vi) memiliki riwayat operasi pada saluran gastrointestinal dalam 6 bulan sebelum penjelasan atau memiliki rencana melakukan operasi dalam masa penelitian, (vii) mengonsumsi obat-obatan lambung seperti antasida, $\mathrm{H}_{2}$ blocker, atau proton pump inhibitor dalam 3 bulan sebelum penjelasan.

\section{Pengobatan yang diterima subjek}

Setiap subjek penelitian memperoleh vitamin $B$ kombinasi dengan komposisi: vitamin $\mathrm{B}_{1}$, vitamin $\mathrm{B}_{6}$, dan vitamin $B_{12}$, dengan dosis secara berurutan $100 \mathrm{mg}, 100 \mathrm{mg}$, dan $5 \mathrm{mg}$. Vitamin B kombinasi tersebut diminum satu kali per hari setelah makan selama 3 bulan. Peninjauan dilakukan sebanyak 5 kali, yaitu peninjauan awal, peninjauan kedua pada hari ke $14 \pm 3$ hari, peninjauan ketiga pada hari ke $30 \pm 3$ hari, peninjauan keempat hari ke $60 \pm 3$ hari, dan peninjauan kelima pada hari ke $90 \pm 3$ hari.

Pada setiap peninjauan dilakukan pemeriksaan gejala klinis neuropati, pemeriksaan kualitas hidup, pemeriksaan fisik rutin, pemeriksaan neurologis, dan pemeriksaan tanda-tanda vital. Pemeriksaan gejala klinis neuropati dilakukan dengan menggunakan Total Symptom Score (TSS). TSS merupakan instrumen yang digunakan untuk menilai frekuensi dan derajat keparahan dari 4 gejala sensoris pada neuropati. Gejala 
neuropati tersebut meliputi sensasi nyeri tertusuk, sensasi nyeri terbakar, kesemutan, dan rasa kebas/baal (Ziegler dkk., 2009). Pemeriksaan kualitas hidup dinilai dengan menggunakan kuesioner SF-8. Perubahan gejala klinis dan kualitas hidup pada peninjauan pertama dan peninjauan terakhir akan dinilai.

\section{Analisis}

Analisis univariat dilakukan untuk mengetahui karakteristik dasar subjek penelitian. Analisis lebih lanjut dengan menggunakan one-way ANOVA untuk mengidentifikasi adanya perbedaan antar kelompok. Wilcoxon signed rank test digunakan untuk mengetahui perubahan skor rata-rata TSS, sedangkan perubahan skor rata-rata QOL dianalisis dengan menggunakan Wilcoxon signed rank test.

\section{Kelaikan etik}

Penelitian ini telah melalui pemeriksaan kelaikan etik dan disetujui oleh Komite Etik Fakultas Kedokteran Universitas Kristen Duta Wacana dengan nomor 166/C.16/FK/2016.

\section{HASIL DAN PEMBAHASAN}

Dalam penelitian ini total terdapat 104 subjek dengan ND. Subjek didominasi oleh laki-laki (61,5\%, dan berusia > 65 taun $(94,2 \%)$. Pada akhir penelitian tersisa $97(93,3 \%)$ subjek. Tujuh subjek tidak dapat mengikuti penelitian ini selama 2 bulan penuh. Tabel 1 menunjukkan skor TSS pada pasien ND secara keseluruhan.

Tabel 1. TSS pada pasien neuropati diabetikum

\begin{tabular}{cc}
\hline Interpretasi TSS & Neuropati Diabetikum \\
\hline TSS Awal $(\mathrm{n}=104)$ & $4,973 \pm 2,1197$ \\
Minimum & 1,00 \\
Maksimum & 10,31 \\
\hline TSS Kelima $(\mathrm{n}=97)$ & $1,693 \pm 1,1445$ \\
Minimum & 0,00 \\
Maksimum & 6,32 \\
\hline Rata-rata Penurunan TSS & $3,307 \pm 1,9327$ \\
Persentase Rata-rata Penurunan TSS & $66,0 \%$ \\
$\mathrm{p}$ & $<0,0001$ \\
\hline
\end{tabular}

TSS: Total Symptom Score

Pasien dengan ND menunjukkan perbaikan klinis pada bulan ketiga setelah pemberian vitamin B kombinasi yang ditunjukkan dengan penurunan skor TSS. Penurunan skor TSS awal ke skor TSS kelima tersebut signifikan secara statistik ( $\mathrm{p}<0,0001)$. Tabel 2 menunjukkan perubahan skor TSS pada kunjungan awal dan pada kunjungan terakhir pada empat gejala ND.

Tabel 2. TSS pada gejala neuropati diabetikum

\begin{tabular}{lllll}
\hline \multirow{2}{*}{ Interpretasi TSS } & \multicolumn{1}{c}{$\begin{array}{c}\text { Sensasi nyeri } \\
\text { tertusuk }\end{array}$} & $\begin{array}{c}\text { Sensasi nyeri } \\
\text { terbakar }\end{array}$ & Kesemutan & Rasa kebas/baal \\
\cline { 2 - 5 } & $1,364 \pm 0,9083$ & $0,733 \pm 0,9188$ & $1,408 \pm 0,9217$ & $1,468 \pm 1,0171$ \\
TSS Awal $(\mathrm{n}=104)$ & 0,00 & 0,00 & 0,00 & 0,00 \\
Minimum & 3,00 & 3,00 & 3,00 & 3,00 \\
Maksimum & $0,440 \pm 0,5697$ & $0,120 \pm 0,3995$ & $0,446 \pm 0,5329$ & $0,687 \pm 0,6686$ \\
TSS Kelima ( $=97)$ & 0,00 & 0,00 & 0,00 & 0,00 \\
Minimum & 2,66 & 0,33 & 1,66 & 2,66 \\
Maksimum & $0,954 \pm 0,8932$ & $0,635 \pm 0,8500$ & $0,981 \pm 0,9295$ & $0,737 \pm 0,8565$ \\
Rata-rata Penurunan & & $83,6 \%$ & $68,3 \%$ & $53,2 \%$ \\
TSS & & & & \\
Persentase Rata-rata & $67,7 \%$ & $<0,0001$ & $<0,0001$ & $<0,0001$ \\
Penurunan TSS & $<0,0001$ & &
\end{tabular}

TSS: Total Symptom Score

Tabel 2 menunjukkan gejala ND yang paling sering muncul adalah rasa kebas/baal (1,468 $\pm 1,0171)$, sedangkan yang paling jarang dirasakan adalah sensasi nyeri terbakar $(0,733 \pm 0,9188)$. Perbaikan pada berbagai gejala tersebut ditunjukkan dengan penurunan
TSS dari peninjauan awal dengan peninjauan kelima. Perubahan skor dari keempat gejala tersebut bermakna secara statistik $(p<0,0001)$. Sensasi nyeri terbakar merupakan gejala dengan persentase penurunan terbanyak $(83,6 \%)$. 
Tabel 3. Skor quality of life

\begin{tabular}{ccccc}
\hline Komponen QoL & PCS & p & MCS & $p$ \\
\hline Skor QoL Awal & $44,142 \pm 6,5215$ & - & $49,198 \pm 9,1910$ & - \\
Skor QoL Ketiga & $47,184 \pm 6,2122$ & $<0,0001$ & $51,298 \pm 7,0736$ & 0,0158 \\
Skor QoL Keempat & $49,332 \pm 6,0685$ & $<0,0001$ & $52,063 \pm 7,1479$ & 0,0132 \\
Skor QoL Kelima & $50,295 \pm 6,3630$ & $<0,0001$ & $53,009 \pm 6,3553$ & 0,0001
\end{tabular}

PCS: Physical Component Summary; MCS: Mental Component Summary; QoL: Quality of Life

Tabel 3 menunjukkan QoL pada pasien dengan ND. Masalah fisik lebih sering dijumpai daripada masalah psikis. Hal tersebut ditunjukkan oleh nilai PCS yang lebih rendah dari MCS. Skor QoL baik PCS maupun MCS selalu mengalami peningkatan, mulai dari peninjauan awal (PCS: 44,142 \pm 6,5215; MCS: $49,198 \pm 9,1910$ ) hingga peninjauan akhir (PCS: 50,295 \pm 6,3630; MCS: 53,009 $\pm 6,3553$ ). Perubahan skor QoL dari peninjauan pertama ke peninjauan kelima tersebut bermakna secara statistik (PCS < 0,0001, MCS = 0,0001).

Penelitian ini menunjukkan bahwa pemberian kombinasi vitamin $B_{1}$, vitamin $B_{6}$, dan vitamin $B_{12}$ dengan dosis masing-masing sebanyak $100 \mathrm{mg}$, $100 \mathrm{mg}$, dan $5 \mathrm{mg}$ selama 3 bulan dapat memperbaiki 4 gejala klinis ND, yang meliputi sensasi nyeri tertusuk, sensasi nyeri terbakar, kesemutan, dan rasa kebas/baal. Hal tersebut dapat dilihat dari penurunan TSS dari kunjungan pertama hingga kunjungan terakhir. Perbaikan dari keempat gejala klinis tersebut bermakna secara statistik $(\mathrm{p}<0,0001)$.

Hasil penelitian ini serupa dengan penelitian oleh Rizvi dkk. (2013). Penelitian Rizvi dkk. (2013) pada 310 pasien ND menunjukkan kombinasi vitamin $B_{1}$, vitamin $\mathrm{B}_{6}$, dan $\mathrm{B}_{12}$ menunjukkan penurunan nyeri pada $87,4 \%$ dari subjek penelitian (Rizvi dkk., 2013). Hasil penelitian oleh Farvid dkk. (2011) menunjukkan pemberian suplementasi $\mathrm{B}_{1}, \mathrm{~B}_{2}, \mathrm{~B}_{6}$, biotin, $\mathrm{B}_{12}$, dan asam folat dengan dosis masing-masing $10 \mathrm{mg}, 10 \mathrm{mg}$, $10 \mathrm{mg}, 200 \mu \mathrm{g}, 10 \mu \mathrm{g}$, dan $1 \mathrm{mg}$, didapatkan penurunan skor MNSI (3,96 menjadi 1,00, $\mathrm{p}=0,01)$. Penelitian pada 100 pasien DM tipe 2 menunjukkan $2000 \mu \mathrm{g}$ vitamin $\mathrm{B}_{12}$ yang diberikan secara intramuskular sebanyak 2 kali per minggu selama 3 bulan menunjukkan penurunan nyeri yang signifikan jika dibandingkan dengan pasien ND yang diberikan $10 \mathrm{mg}$ nortriptilin setiap malam (Talaei dkk., 2009).

Penelitian ini juga menunjukkan adanya peningkatan QoL pada pasien dengan ND setelah pemberian vitamin B kombinasi selama 3 bulan. Terdapat peningkatan skor PCS dan MCS dari peninjauan pertama hingga peninjauan kelima. Peningkatan tersebut bermakna secara statistik (PCS < 0,0001, MCS $=0,0001)$. Hasil ini selaras dengan penelitian Fonseca dkk., (2013). Penelitian double-blind pada 106 subjek DM tipe 2 yang memperoleh terapi metilfolat, vitamin $\mathrm{B}_{6}$, dan vitamin $\mathrm{B}_{12}$, dengan dosis masing-masing $3 \mathrm{mg}, 35 \mathrm{mg}$, dan $2 \mathrm{mg}$, dibandingkan dengan 108 subjek DM tipe 2 yang memperoleh plasebo. Hasil dari penelitian tersebut menunjukkan subjek dengan terapi metilfolat $3 \mathrm{mg}$, vitamin $\mathrm{B}_{6} 35 \mathrm{mg}$, dan vitamin $\mathrm{B}_{12} 2 \mathrm{mg}$ mengalami penurunan nyeri, perbaikan gejala klinis, dan peningkatan QoL yang signifikan (Fonseca dkk., 2013).

Pada penelitian ini, komponen fisik lebih sering menimbulkan permasalahan bagi para pasien jika dibandingkan dengan komponen psikologi. Hal ini ditunjukkan dengan skor QoL yang lebih rendah pada PCS mulai dari kunjungan pertama hingga kunjungan kelima. Hasil ini serupa dengan penelitian terdahulu oleh Happich dkk., (2008) dan Van dkk. (2009) yang menyatakan permasalahan fisik lebih sering dijumpai pada pasien dengan ND. Penelitian terdahulu yang menyatakan bahwa permasalahan fisik yang sering mengganggu QoL pasien adalah sensasi nyeri terbakar pada kaki, rasa kebas/baal, kelemahan pada kedua kaki, instabilitas ketika berdiri atau berjalan, dan ketidakmampuan untuk melakukan aktivitas hobi. Permasalahan psikis yang sering mengganggu QoL pasien ND adalah adanya perasaan ketergantungan pada pertolongan orang lain, peran mereka dalam keluarga berubah, merasa lebih tua dari usia yang seharusnya, merasa hidup menjadi lebih berat, dan merasa malu (Ahmed, 2017).

Terdapat 8 jenis vitamin $B$, yaitu vitamin $B_{1}, B_{2}$, $\mathrm{B}_{3}, \mathrm{~B}_{5}, \mathrm{~B}_{6}, \mathrm{~B}_{7}, \mathrm{~B}_{9}$, dan $\mathrm{B}_{12}$. Vitamin $\mathrm{B}_{1}$ bekerja sebagai anti oksidan dan memiliki efek pada nitric oxide-cGMP pathway yang memberikan efek anti alodinia dan anti hiperalgesia (Alvarado \& Navarro, 2016). Hal tersebut dicapai melalui penghambatan berbagai jalur, meliputi diacylglycerol protein kinase $C$ pathway, advanced glycation end-product formation pathway, dan hexamine pathway (Geller dkk., 2017). Defisiensi thiamin terkait dengan DM tipe 2 (Ramos dkk., 2015). Sekitar 75\% penderita DM tipe 2 memiliki kadar thiamin dalam plasma yang rendah (Vin \& Thi, 2012). 
Vitamin $\mathrm{B}_{6}$ bekerja pada kanal kalsium, menghambat sintesis glutamat, dan meregulasi metabolisme karbohidrat (Alvarado \& Navarro, 2016). Selain itu, vitamin $\mathrm{B}_{6}$ juga bekerja dengan menghambat pelepasan neurotransmitter presinaptik dari serabut saraf nosiseptif dan menghambat hipereksitabilitas neuron (Geller dkk., 2017).

Vitamin $B_{12}$ memiliki efek rekonstruktif dan meningkatkan sintesis epidermal growth factor yang merupakan faktor myelotropik (Alvarado \& Navarro, 2016). Vitamin $B_{12}$ dapat memicu regenerasi saraf dan/atau remyelinasi dengan adanya akumulasi vitamin $B_{12}$ eksogen (Geller dkk., 2017). Metformin merupakan salah satu obat yang sering digunakan oleh pasien DM. Penggunaan metformin jangka panjang sering terkait dengan malabsorpsi vitamin $\mathrm{B}_{12}$ yang menimbulkan defisiensi vitamin $\mathrm{B}_{12}$ (Fatima \& Noor, 2013; Reinstatler dkk., 2012). Defisiensi vitamin $B_{12}$ tersebut merupakan salah satu pemicu munculnya neuropati perifer pada pasien DM (Jeetendra \& Tushar, 2016), khususnya pada usia $\geq 65$ tahun (Zagar \& Longyhore, 2014). Oleh karena itu, pasien DM yang memperoleh pengobatan metformin jangka lama (> 6 bulan) disarankan untuk juga memperoleh suplementasi vitamin $\mathrm{B}_{12}$ untuk mencegah terjadinya ND (Roy dkk., 2016).

Kombinasi dari ketiga vitamin B tersebut dapat menangani berbagai kondisi salah satunya adalah nyeri (Alvarado \& Navarro, 2016). Manfaat dari kombinasi vitamin B tersebut dapat dibedakan menjadi dua, yaitu menurunkan efek kerusakan pada serabut saraf serta efek anti-nosiseptif dan anti hiperalgesia (Mimenza \& Aguilar, 2014).

Keterbatasan penelitian ini adalah tidak ada kelompok pembanding. Peneliti hanya membandingkan skor nyeri dan kualitas hidup pada satu kelompok antara sebelum dan sesudah pemberian kombinasi vitamin $\mathrm{B}$.

\section{KESIMPULAN}

Pemberian kombinasi vitamin $\mathrm{B}_{1}$, vitamin $\mathrm{B}_{6}$, dan vitamin $\mathrm{B}_{12}$, dengan dosis masing-masing $100 \mathrm{mg}$, $100 \mathrm{mg}$, dan $5 \mathrm{mg}$, sebanyak satu kali per hari selama 3 bulan dapat memperbaiki 4 gejala utama ND yang meliputi sensasi nyeri tertusuk, sensasi nyeri terbakar, kesemutan, dan rasa kebas/baal. Pemberian vitamin B kombinasi ini juga dapat meningkatkan QoL pasien ND baik dari segi fisik maupun psikis.

\section{DAFTAR PUSTAKA}

Ahmed, A. S. (2017). Assessment of Quality of Life of Patients with Diabetic Peripheral Neuropathy. IOSR. Journal of Nursing and Health Science; 6; 37-46.

Al-Geffari, M. (2012). Comparison of Different Screening Tests for Diagnosis of Diabetic Peripheral Neuropathy in Primary Health Care setting. International Journal of Health Sciences, Qassim University; 6; 127-134.

Alvarado, A. M. \& Navarro, S. A. (2016). Complex B Vitamins: Physiology and Therapeutic Effect on Pain. American Journal of Pharmacological Sciences; 4; 20-27.

Badan Penelitian dan Pengembangan Kesehatan Kementerian Kesehatan Republik Indonesia. (2013). Riset Kesehatan Dasar (Riskesdas) 2013. Jakarta: Bakti Husada.

Boyd, A., Casselini, C., Vinik, E. \& Vinik, A. (2011). Quality of Life and Objective Measures of Diabetic Neuropathy in a Prospective PlaceboControlled Trial of Ruboxistaurin and Topiramate. Journal of Diabetes Science and Technology; 5; 714-722.

Bril, V., Tomioka, S., Buchanan, R.A. \& Perkins, A. (2009). Complications Reliability and Validity of the Modified Toronto Clinical Neuropathy Score in Diabetic Sensorimotor Polyneuropathy. Diabetic Medicine; 26; 240-246.

Burns, T. \& Mauermann, M. (2011). The Evaluation of Poluneuropathies. Neurology; 76; 6-13.

Deli, G., Bosnyak, E., Pusch, G., Komoly, S. \& Feher, G. (2013). Diabetic Neuropathies: Diagnosis and Management. Neuroendocrinology; 98; 267280.

Deshpande, A. D., Harris-Hayes, M. \& Schootman, M. (2008). Epidemiology of Diabetes and Diabetesrelated Complications. Physical Therapy; 88; 1254-1264.

Do Nascimento, O. J. M, Pupe C. C. B. \& Cavalcanti E. B. U. (2016). Diabetic Neuropathy. Revista Dor São Paulo; 17; S46-51.

Farvid, M. S., Homayouni, F., Amiri, Z. \& Adelmanesh, F. (2011). Improving Neuropathy Scores in Type 2 Diabetic Patients Using Micronutrients Supplementation. Diabetes Research and Clinical Practice; 93; 86-94. 
Fatima, S. \& Noor, S. (2013). A Review on Effects of Metformin on Vitamin B12 Status. American Journal of Phytomedicine and Clinical Therapeutics; 8; 652-660.

Fonseca, V. A., Lavery, L. A., Thethi, T. K., Daoud, Y., DeSouza, C., Denham, D. S., Bottiglieri, T., Sheehan, P. \& Rosenstock, J. (2013). Metanx in Type 2 Diabetes with Peripheralneuropathy: A Randomized Trial. The American Journal of Medicine; 126; 141-149.

Geller, M., Oliveira, L., Nigri1, R., Mezitis, S. G., Ribeiro, M. G., Fonseca, A. D. S. D., Guimarães, O. R., Kaufman, R. \& Wajnsztajn, F. (2017). B Vitamins for Neuropathy and Neuropathic Pain. Vitamins \& Minerals; 6; 161.

Happich, M., John, J., Stamenitis, S., Clouth, J. \& Polnau, D. (2008). The Quality of Life and Economic Burden of Neuropathy in Diabetic Patients in Germany in 2002-Results from the Diabetic Microvascular Complications (DIMICO) Study. Diabetes Research and Clinical Practice; 81; 223-230.

Hosseini, A. \& Abdollahi, M. (2013). Diabetic Neuropathy and Oxidative Stress: Therapeutic Perspectives. Oxidative Medicine and Cellular Longevity; 2013; 1-15.

Jeetendra, S. \& Tushar, B. (2016). Metformin Use and Vitamin B12 Deficiency in Patients with Type-2 Diabetes Mellitus. Journal of Medical Sciences; 3; 67-70.

Kovac, B., Kovac, B., Marusic-Emedi, S., Svalina, S. \& Demarin, V. (2011). Clinical and Electrophysiological Signs of Diabetic Polyneuropathy - Effect of Glycemia and Duration of Diabetes Mellitus. Acta Clinica Croatica; 50; 149-157.

Mimenza, A. J. \& Aguilar, S. G. (2014). Comparative Clinical Trial of Safety and Tolerability of Gabapentin Plus Vitamin B1/B12 Versus Pregabalin in the Treatment of Painful Peripheral. Journal of Pain and Relief; 3; 1-6.

Muntean, C., Catalin, B., Tudorica, V. \& Mota, M. (2016). Efficiency of Michigan Neuropathy Screening Instrument and Nerve Conduction Studies for Diagnosis of Diabetic Distal Symmetric Polyneuropathy. Romanian Journal of Diabetes Nutrition and Metabolic Diseases; 23; 55-65.

Papanas, N., Vinik, A. I. \& Ziegler, D. (2011). Neuropathy in Prediabetes: Does the Clock Start
Ticking Early? Nature Reviews Endocrinology; 7; 682-690.

Pop-Busui, R., Boulton, A. J. M., Feldman, E. L., Bril, V., Freeman, R., Malik, R. Z., Jay, M. S. \& Dan, Z. (2017). Diabetic Neuropathy: A Position Statement by the American Diabetes Association. Diabetes Care; 40; 136-154.

Ramos, R. V., Laura, G. L. A., Elina, M. C. B. \& Donaji, B. A. A. (2015). Vitamins and Type 2 Diabetes Mellitus: Endocrine, Metabolic \& Immune Disorders. Drug Targets; 15; 54-63.

Reinstatler, L., Qi, Y. P., Williamson, R. S., Garn, J. V. \& Oakley, G. P. (2012). Association of Biochemical B12 Deficiency with Metformin Therapy and Vitamin B12 Supplements. Diabetes Care; 35; 327-333.

Rizvi, A., Ahmad, A. \& Rizvi, Z. (2013). Efficacy of Combination of Vitamin B1, B6 and B12 in Management of Diabetic Peripheral Neuropathy. Pakistan Journal of Medical Sciences; 7; 801804.

Roy, R. P, Ghosh, K., Ghosh, M., Acharyya, A., Bhattacharya, A., Pal, M., Chakraborty, S. \& Sengupta, N. (2016). Study of Vitamin B Deficiency and Peripheral Neuropathy in Metformin-Treated Early Type 2 Diabetes Mellitus. Indian Journal of Endocrinology and Metabolism; 20; 631-637.

Talaei, A., Siavash, M., Majidi, H. \& Chehrei, A. (2009). Vitamin B12 Maybe More Effective than Nortriptyline in Improving Painful Neuropathy. International Journal of Food Sciences and Nutrition; 60; 71-76.

Tesfaye, S., Boulton, A. J. \& Dickenson, A. (2013). Mechanisms and Management of Diabetic Painful Distal Symmetrical Polyneuropathy. Diabetes Care; 36; 2456-2465.

Van, A. K., Bouhassira, D., De B. D., Matthys, K., Raemen, H., Mathieu, C. \& Colin, I. M. (2009). Prevalence and Impact on Quality of Life of Peripheral Neuropathy With or Without Neuropathic Pain in Type 1 and Type 2 Diabetic Patients Attending Hospital Outpatients Clinics. Diabetes \& Metabolism; 35; 206-213.

Vin O. L. K. \& Thi, H. L. (2012). The Impact of the Thiamine Treatment in the Diabetes Mellitus. Journal of Clinical Medicine Research; 4; 153160.

Yagihashi, S., Mizukami, H. \& Sugimoto, K. (2010). Mechanism of Diabetic Neuropathy: Where are 
We Now and Where to Go?. Journal of Diabetes Investigation; 2; 18-32.

Zagar, B. R. \& Longyhore, D. S. (2014). Evaluating the Association between Vitamin B12 Deficiency and Peripheral Neuropathy in Patients with Diabetes. International Journal of Medicine and Pharmacy; 2; 1-10.

Ziegler, D., Movsesyan, L., Mankovsky, B., Gurieva, I., Abylaiuly, Z. \& Strokov, I. (2009). Treatment of Symptomatic Polyneuropathy with Actovegin in Type 2 Diabetic Patients. Diabetes Care; 32; 1479-1484.

Zychowska, M., Rojewska, E., Przewlocka, B. \& Mika, J. (2013). Mechanisms and Pharmacology of Diabetic Neuropathy - Experimental and Clinical Studies. Pharmacological Reports; 65; 1601-1610. 